The Chittagong Univ. J. B. Sci., Vol. 6(1 \&2):147-158, 2011.

\title{
STUDY OF MICROGASTRINAE NEES 1814 (HYMENOPTERA: BRACONIDAE) IN BANGLADESH
}

\author{
M. HABIBUR RAHMAN * \\ Department of Zoology, University of Chittagong, Chittagong 4331, Bangladesh
}

\begin{abstract}
Three genera of Microgastrinae (Hymenoptera: Braconidae) have been described and illustrated from Bangladesh and a key for the genera was prepared. The genera are Apanteles Foerster, Microplitis Foerster, and Protomicroplitis Ashmead. The genus Protomicroplitis is the new record to the fauna of Bangladesh.
\end{abstract}

Key words: New record, braconid, microgastrine, endoparasitoid.

\section{INTRODUCTION}

Microgastrinae are the most important single group of parasitoids of Lepidoptera in the world. Mason (1981) estimated that the actual world total is likely between 5,000 and 10,000 species; at present over 1,400 species have been described. With about 2,000 described species (Yu et al. 2005) and an estimate total of 5,000-10,000 species (Mason 1981, Whitfield 1997), the Microgastrinae (Hymenoptera, Braconidae) is one of the most specious groups of parasitic wasps. Since the last available catalogs of World species (Shenefelt 1972, 1973), several additional new works have been published.

The classification of Microgastrinae has become more complex over the last three decades. Nixon (1965) erected two new genera for Neotropical species, and resurrected other generic names from obscurity, increasing the number of genera recognized from the New World from approximately eight to 13. With Mason's (1981) landmark but controversial reclassification, the New World species were redistributed into 41 genera, 18 of them newly created.

Microgastrine species attack virtually the entire taxonomic and biological spectrum of Lepidoptera, with the possible exception of Hepialidae (Wharton et al. 1997). All species are koinobiont, endoparasitoids of larvae, and exit the host to pupate. More than 100 species in this group have been used or investigated worldwide in the biological control of pest Lepidoptera, and this total is likely to rise (Wharton et al. 1997).

In Bangladesh, limited taxonomic works on parasitic microgastrine have been done [e.g., Alam (1962), Alam et al. (1964), Gapud (1992), Ahmed and Jalil

*corresponding author:mhrahman_cu@yahoo.com 
(1993) and Ali et al., (1993) listed different species of Apanteles and their hosts from different parts of the country]. Keeping the above-mentioned fact in mind, the present study was undertaken with the following objectives: (i) to collect and study the microgastrine diversity in some selected areas of Bangladesh; (ii) to study the taxonomy of parasitic microgastrine with information of their distribution and biology and effectiveness of their biocontrol activity; and iii) to prepare a list of the microgastrine genera found in different pars of Bangladesh by Malaise trap.

\section{MATERIALS AND METHODS}

Collections of specimens of microgastrines were made from different areas of Cox's Bazar, Chittagong (Sitakundo), Rangamati and Faridpur districts of Bangladesh. A total of three genera were sorted out during 2004 to 2006. The insects were collected by using sweep net and Malaise Traps. The collected specimens were brought to the laboratory and were mounted dry with pins on cards. Stainless steel, continental size pins with and without head were used for mounting. Some specimens were preserved in $70 \%$ alcohol. The specimens were identified on the basis of the external morphological features viewed under a binocular microscope and drawn sketches with the help of a camera lucida. The terminology used to describe the characteristic morphological features of Hymenoptera and Braconidae were according to Achterberg (1979, 1993 and 1997) Shaw and Huddleston (1991), Goulet and Huber (1993) and Wharton et al. (1997). The identification of the specimens up to generic level was confirmed by D. L. J. Quicke, Department of Biology, Imperial College of Science, Technology and Medicine, London, UK (personal communication). The females of microgastrine genera are described in this paper and the type materials are stored in the Zoological Museum of Chittagong University, Bangladesh (ZMCU). Asterisk (*) has been used for new record to the fauna of Bangladesh.

\section{RESULTS AND DISCUSSION}

\section{Distinguishing features of Microgastrinae}

All Microgastrinae have exactly 18 antennal segments (though these may appear subdivided when placode sensilla are evenly arranged in two ranks per flagellomere). They also have the spiracles of the first metasomal segment (= petiole) situated on the lateral tergites, rather than on the median tergite, and tend to have apically reduced wing venation (Figs. 1, 2, 10 and 11). These features should serve to distinguish microgastrines from all other braconids. Microgastrines are characterised by their invariably 18-segmented antennae 
STUDY OF MICROGASTRINAE NEES 1814 (HYMENOPTERA: BRACONIDAE) IN BANGLADESH

[though basal flagellar segments are sometimes constricted centrally so that each may appear as two (Fig. 4)]; they generally also have a short metasoma and large hind coxae (Fig. 7); second submarginal cell ('open' in Apanteles sensu lato) is a character otherwise seen only in Agathidinae, which differ markedly in having a short and narrow marginal cell (Figs. 1, 10, 20 and 21).

Key To The Bangladeshi Genera Of The Subfamily Microgastrinae (Figs. 1-27)

1. Second submarginal cell of fore wing closed distally by $r-m$, forming tiny to moderate- sized cell or areolet .............................................. 2 - Second submarginal cell open distally, either through loss of r-m or fusion of this vein with other veins

2. Petiole with strong, usually narrow, antero-median longitudinal groove over most of length 3

- Petiole with broad antero-median depression but without strong antero-median longitudinal groove

3. Mesopleuron without distinct epicnemial carina; mesosoma variable but rarely extremely coarsely sculptured except on propodeum; metasomal terga 2 and 3 variable but usually with well-defined median area that is raised and often also sculptured........4 - Mesopleuron with distinct epicnemial carina; mesosoma very coarsely sculptured. Metasomal terga 2 and 3 smooth and without welldefined median raised and sculptured area (belonging to Snellenius Westwood) Not studied

4. Median tergite of petiole at least 1.5 times longer than maximum width and usually either much more slender than this, or narrowing posteriorly; hind coxa variable . .5

- Petiole broad, somewhat rectangular in outline, often but not always strongly sculptured. Hind coxa greatly enlarged (belonging to Diolcogaster Ashmead).. Not studied

5. Vannal lobe strongly convex and separated from rest of margin of wing by a notch. Propodeum strongly rugose with a median carina; petiole extremely narrow, with sides broadly but weakly emarginate (Figs. 20-27) Protomicroplitis Ashmead

- Vannal lobe of hind wing reduced, not clearly set off from rest of margin of wing by a notch; propodeum smooth or nearly so, with strong median carina; large and often strikingly coloured (belonging to Larissimus Nixon) ..Not studied 
6. Metasomal tergum 2 unsculptured, and longer than wide in some species; occasionally with narrow, median raised region on this tergite; flagellomeres usually with 2 ranks of placodes, thus often appearing subdivided 7

- Metasomal tergum 2 with median tergite strongly sculptured and broad, rectangular to subrectangular and covering most or all of dorsal width of tergum; with no narrow, median raised region on this tergite; flagellomeres with placodes arranged irregularly, thus flagellomeres not appearing subdivided (belonging to Hygroplitis Thomson).

Not studied

7. Vannal lobe not reduced 8

- Vannal lobe of hind wing strongly reduced (belonging to Prasmodon Nixon) Not studied

8. Propodeum variously sculptured, usually strongly rugose, and often showing traces of a median carina ovipositor sheaths short and with setae concentrated apically; second submarginal cell small; hind wing 2r-m typically present but not pigmented (Figs. 10-19) ...............................Microplitis Foerster (in part) - Propodeum completely smooth and polished; ovipositor sheaths as long as or longer than hind tibia. Second submarginal cell of fore wing large; hind wing 2r$\mathrm{m}$ absent, even as a spectral vein (belonging to Pelicope Mason)..........Not studied 9. Metasomal terga 1-3 variable in shape but never with pebble-grained, coriaceous surface: usually smooth, punctate, aciculo-rugose or rugulose ........10 - Metasomal terga 1 and 2 broad, covering entire width of tergum and with a pebble-grained, coriaceous surface (belonging to Xanthapantales Whitfield)...Not studied 10. Posterior courses of notauli with somewhat denser, more longitudinally elongate, and confluent punctation; vannal lobe of hind wing not uniformly fringed with setae, slightly to strongly flattened or slightly concave in outline subapically and either setae absent or more sparsely setose over this flattened or concave portion; hypopygium nearly always medially desclerotized into expandable pleats (Figs. 1-9.......Apanteles Foerster (in part)

- Mesoscutum with even, distinct punctation even along posterior courses of notauli, or punctation indistinct posteriorly; vannal lobe of hind wing evenly convex to slightly flattened subapically and evenly fringed with setae; hypopygium variable .............. 11

11. Hypopygium long and medially desclerotized into expandable pleats; body length variable but usually greater than $2.3 \mathrm{~mm}$.................................... 12 - Hypopygium sharply folded medially and evenly sclerotized, though sometimes slightly more translucent and flexible postero-medially, never with expandable 
STUDY OF MICROGASTRINAE NEES 1814 (HYMENOPTERA: BRACONIDAE) IN BANGLADESH

pleats; body length often less than $2.2 \mathrm{~mm}$ (belonging to Parapantales Ashmead)............. Not studied

12. Vannal lobe of hind wing slightly to strongly flattened to concave subapically, with fringe of setae sparser or absent over the flattened or concave part. Petiole usually slightly to strongly narrowing posteriorly (Figs. 1-9).... Apanteles Foerster - Vannal lobe of hind wing evenly convex and uniformly fringed with setae. Petiole usually barrel-shaped or nearly parallel-sided and broader posteriorly to subequal in width anteriorly and posteriorly (belonging to (belonging to Exoryza Mason) Not studied

\section{Description of the genera}

Apanteles Foerster 1862 (Figs. 1-9)

Cotesia Cameron, 1891

Protapanteles ephyrae Ashmead, 1898; Apanteles paleacritae Riley, 1881).

Cryptapanteles Viereck, 1910: 209; Shenefelt, 1972: 430; Apanteles Foerster, 1862); Cryptapanteles rileyanus Viereck, 1910; Apanteles scitulus Riley, 1881). Verh. Naturh. Ver. Preuss. Rheinl. 19: 245. 


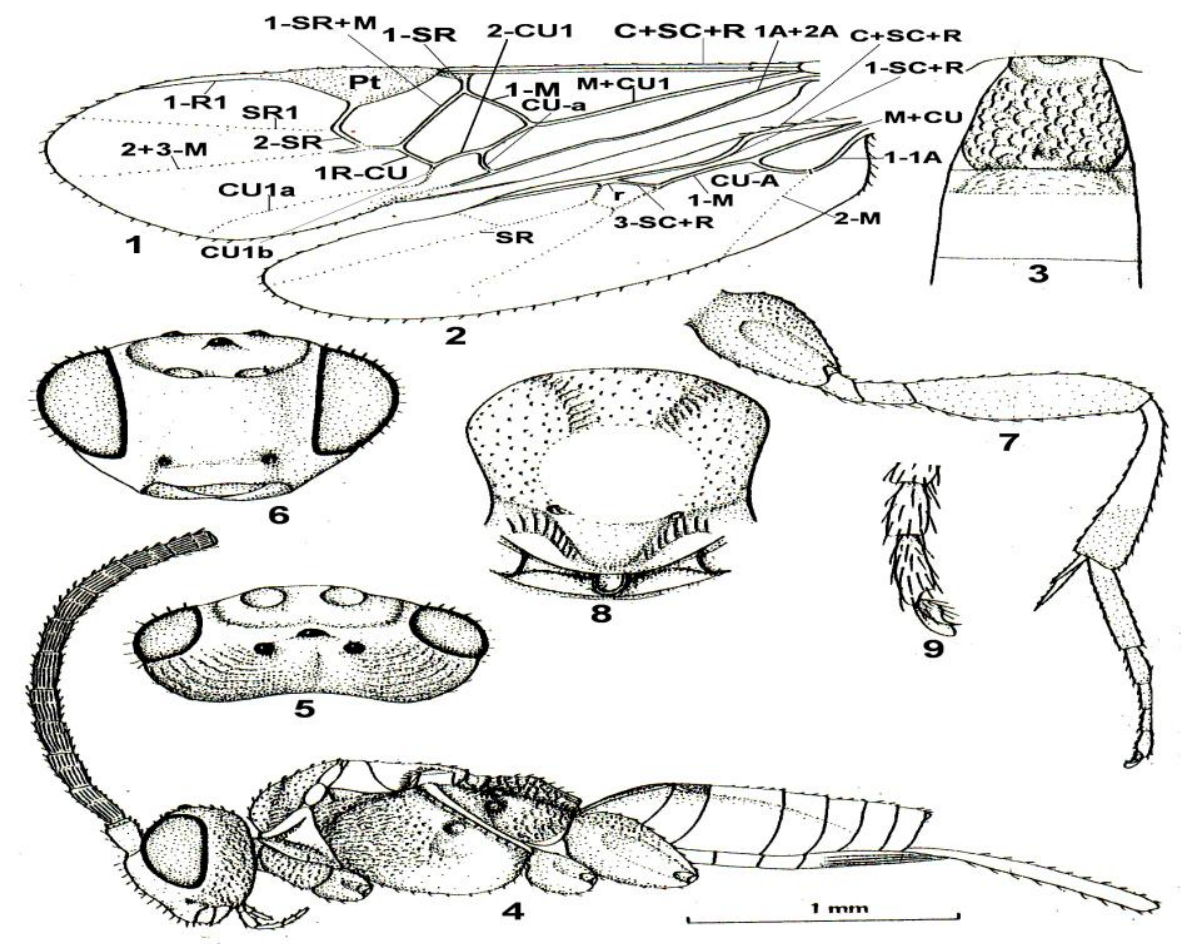

FIGS. 1-9: APANTELES SP., +. 1, FORE WING; 2, HIND WING; 3, FIRST AND SECOND METASOMAL TERGITES, DORSAL ASPECT; 4, HABITUS, LATERAL ASPECT; 5, HEAD, DORSAL ASPECT; 6, HEAD, FRONTAL ASPECT; 7, HIND LEG; 8, MESOSOMA, DORSAL ASPECT; AND 9, INNER HIND CLAW. [WINGS ABBREVIATIONS: $\mathrm{A}=$ ANALIS; $\mathrm{C}=\mathrm{COSTA} ; \mathrm{CU}=$ CUBITUS; $\mathrm{M}=$ MEDIA; $\mathrm{R}=$ RADIUS; $\mathrm{SC}=$ SUBCOSTA; $\mathrm{SR}=$ SECTORADII; SR $1=1^{\text {ST }}$ ABSCISSA OF RADIUS; A $=$ TRANSVERSE ANAL VEIN; CU-A = TRANSVERSE CUBITO-ANAL VEIN; M-CU = TRANSVERSE MEDIO-CUBITAL VEIN; $\mathrm{R}=$ TRANSVERSE RADIAL VEIN; R-M = TRANSVERSE RADIO-MEDIAL VEIN; 2R-M/2SR $=1^{\text {ST }}$ TRANSVERSE RADIAL VEIN; PT = PTEROSTIGMA; 1R-M = NERVULUS/ BASELLA/ BASALIS; 1 -CU1 $=1^{\mathrm{ST}}$ ABSCISSA OF DISCOIDELLUS; 2-CU1 $=2^{\mathrm{ND}}$ ABSCISSA OF DISCOIDELLUS; 3 -CU1 $=3^{\mathrm{RD}}$ ABSCISSA OF DISCOIDELLUS; $\mathrm{CU} 1 \mathrm{~A} / 3-\mathrm{CU}=\mathrm{APICAL}$ ABSCISSA OF SUBDISCOIDELLUS]. 
STUDY OF MICROGASTRINAE NEES 1814 (HYMENOPTERA: BRACONIDAE) IN BANGLADESH

\section{Diagnosis}

Very large genus with more than 1000 species; they have long ovipositors used to reach more or less concealed living hosts and the more or less modified hypopygium of the female; the plical or anal lobe of the hind wing lacking partly a fringe of setae (Fig. 2); metasomal terga 1-3 variable, sometimes enlarged and heavily sculptured (Fig. 3) but still with tergum 1 normally articulating with tergum 2 (Fig. 3); second submarginal cell open distally, either through loss of $r$ $\mathrm{m}$ or fusion of this vein with other veins (Fig. 1); propodeum with a welldeveloped areola defined by lateral carinae, at least posteriorly (Fig. 4); propodeum without median longitudinal carina, or with a median carina extending only over anterior to the areola (Fig. 4); petiole usually slightly to strongly narrowing posteriorly and variable in shape and sculpture but never with the above pattern of ridges and groove; face usually same colour as rest of head (Fig. 3); hypopygium long and variable but often desclerotized into expandable pleats; metasomal terga 1-3 variable in shape but never with pebble-grained, coriaceous surface: usually smooth, punctate, aciculo-rugose or rugulose (Fig. 3). Distribution: Cox's Bazar and Sitakundo, Bangladesh.

Materials examined: BANGLADESH: Cox's Bazar, one ㅇ. Apanteles sp., 10.IX.1999; Collected by- Arjeena; Sitakundo, Chittagong, two 9. Apanteles sp., 15.XII.2000; 7.VII.2000. Collected by- Shafkat. Specimens deposited in ZMCU

Microplitis Foerster 1862 (Figs. 10-19)

Verh. naturh. Ver. preuss. Rheinl. 19: 245.

\section{Diagnosis}

Metasomal terga 1-3 variable, sometimes enlarged and heavily sculptured (Fig. 16) but still with tergum 1 normally articulating with tergum 2 (Fig. 16); second submarginal cell 


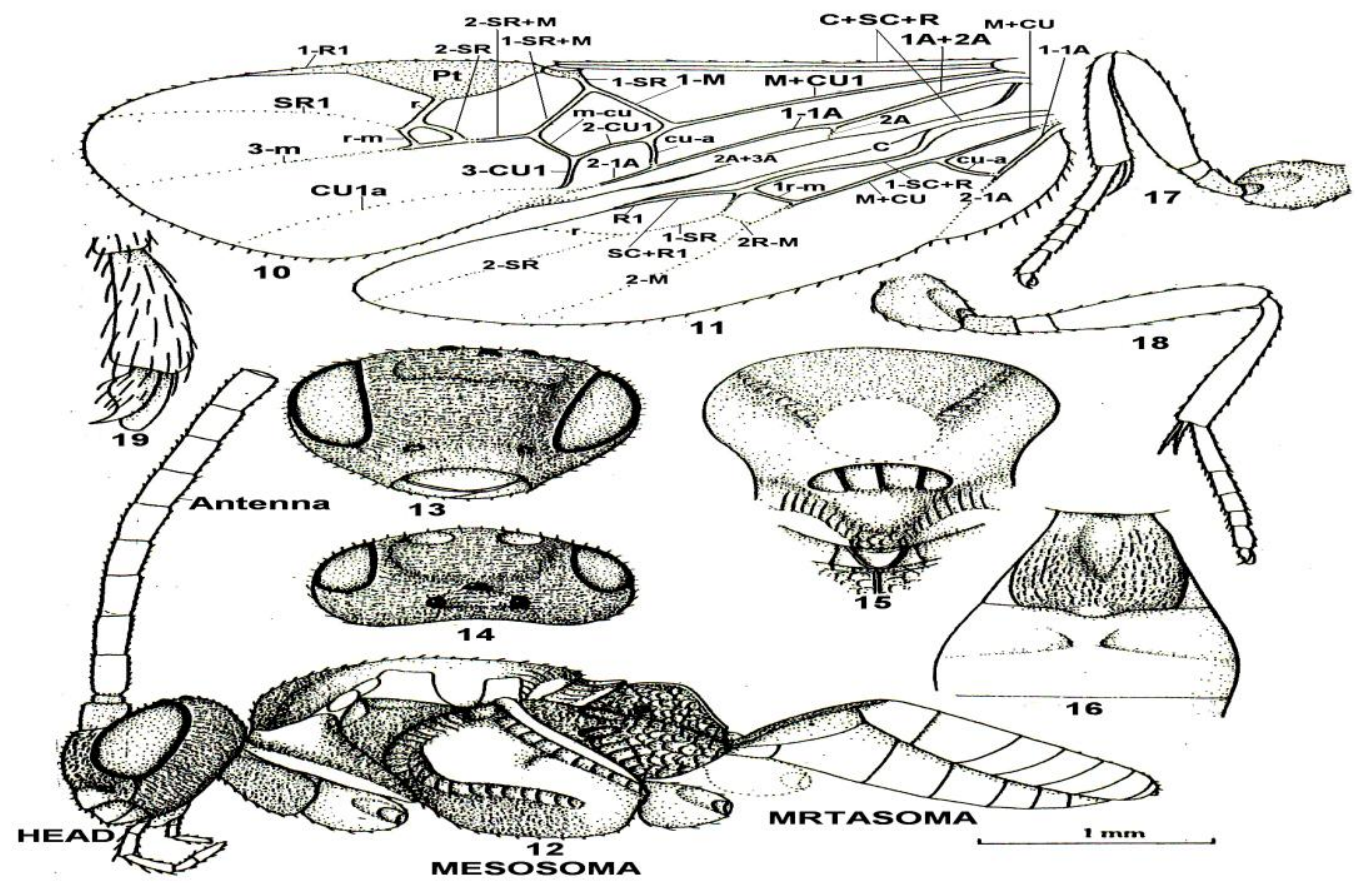

FIGS. 10-19: MICROPLITIS SP., O. [10, FORE WING; 11, HIND WING; 12, HABITUS, LATERAL ASPECT; 13, HEAD, FRONTAL ASPECT; 14, HEAD, DORSAL ASPECT; 15, MESOSOMA, DORSAL ASPECT; 16, METASOMA, FIRST THREE TERGITES, DORSAL ASPECT; 17, FORE LEG; 18, HIND LEG; AND 19, INNER HIND CLAW. 10-12, 17, 18: 1.0 X SCALE LINE; 1316: $2.5 \mathrm{X}$ (WINGS ABBREEVIATIONS ARE GIVEN IN FIGS. 1-9). OF FORE WING CLOSED DISTALLY BY R-M, FORMING TINY TO MODERATESIZED CELL OR AREOLET (FIG. 10); SECOND SUBMARGINAL CELL SMALL (FIG. 10); HIND WING 2R-M TYPICALLY PRESENT BUT NOT PIGMENTED (FIG. 11); PROPODEUM WITHOUT A DISTINCT AREOLA (FIG. 12); OFTEN WITH EITHER A MEDIAN LONGITUDINAL CARINA OR WITH POORLY DEFINED PATTERN OF CARINAE; PROPODEUM VARIOUSLY SCULPTURED, USUALLY STRONGLY RUGOSE; PETIOLE WITH BROAD ANTERO-MEDIAN DEPRESSION BUT WITHOUT STRONG ANTERO-MEDIAN LONGITUDINAL GROOVE (FIG. 16); PROPODEUM WITHOUT CLEARLY 
STUDY OF MICROGASTRINAE NEES 1814 (HYMENOPTERA: BRACONIDAE) IN BANGLADESH

DEFINED TRANSVERSE CARINA, SOMETIMES ALSO WITHOUT DISTINCT MEDIAN LONGITUDINAL CARINA (FIG. 12); HEAD NOT USUALLY ANTERO-POSTERIORLY THIN AND GLOSSA NOT DEEPLY BILOBED (FIGS. 13, 14); OVIPOSITOR SHEATHS VARIABLE; HYPOPYGIUM VARIABLE BUT OFTEN EVENLY SCLEROTIZED TO MEDIAN FOLD; MESOSCUTUM WITH WELL-DEFINED NOTAULI, AT LEAST OVER ANTERIOR HALF (FIG. 15); METASOMAL TERGUM 2 UNSCULPTURED OR VERY SLIGHTLY SCULPTURED (FIG. 16); OCCASIONALLY WITH NARROW, MEDIAN RAISED REGION ON THIS TERGITE (FIG. 16); FLAGELLOMERES USUALLY WITH 2 RANKS OF PLACODES, THUS OFTEN APPEARING SUBDIVIDED (FIG. 12); OVIPOSITOR SHEATHS SHORT AND WITH SETAE CONCENTRATED APICALLY.]

Distribution: Rangamati, Bangladesh.

Materials examined: BANGLADESH: Rangamati, one + . Microplitis sp., 5.IX.2000. Collected by- Shafkat. Specimen deposited in ZMCU.

Protomicroplitis Ashmead 1898 (*) (Figs. 20-27)

Proc. Ent. Soc. Wash. 4: 167.

\section{Diagnosis}

Metasomal terga 1-3 variable and tergum 1 normally articulating with tergum 2 (Fig. 23); second submarginal cell of fore wing closed distally by r-m, forming tiny to moderatesized cell or areolet (Fig. 20); petiole with strong, usually narrow, antero-median longitudinal groove over most of length (Fig. 25); mesopleuron without distinct epicnemial carina; mesosoma variable but rarely extremely coarsely sculptured except on propodeum (Fig. 24); metasomal terga variable but ususally with well defined median area that is raised and often also sculptured (Fig. 25); median tergite of petiole at least 1.5 times longer than maximum width and usually either much more slender than this, or narrowing posteriorly (Fig. 25); hind coxa variable; antennal placodes arranged irregularly, rarely in roughly 3 ranks, thus anennal segments not appearing to be divided into two halves; anal lobe strongly convex and separated from rest of margin of wing by a notch (Fig. 21); propodeum strongly rugose with a median carina (Fig. 24); petiole extremely narrow, with sides broadly but weakly emarginate (Fig. 25). 
HABIBUR RAHMAN

Distribution: Faridpur, Bangladesh.

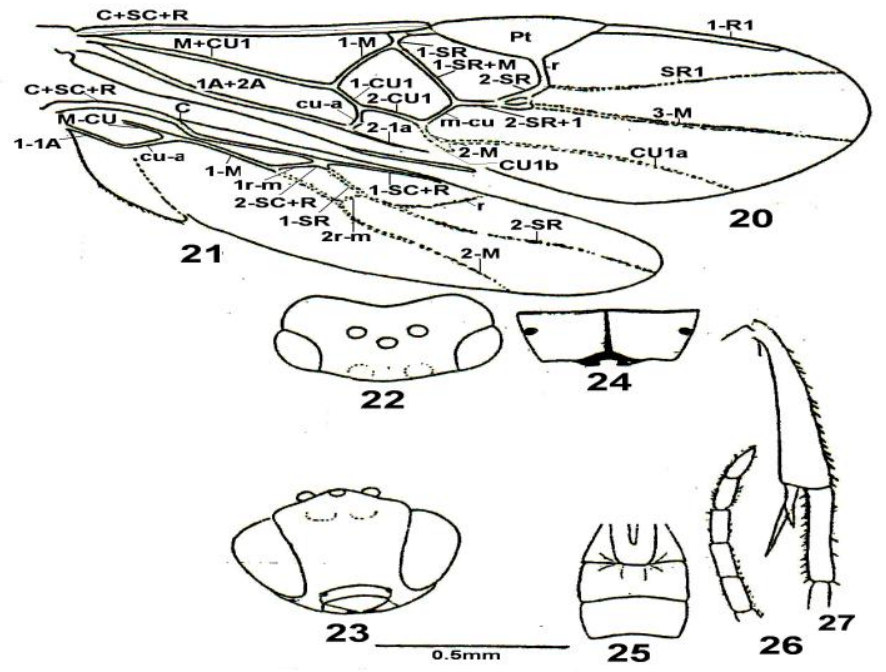

FIGS. 20-27. PROTOMICROPLITIS SP., †. 20, FORE WING; 21, HIND WING; 22, HEAD, DORSAL ASPECT; 23, HEAD, FRONTAL ASPECT; 24, PROPODEUM; 25, BASAL FIRST THREE ABDOMINAL TERGITES; 26, TERMINAL FIVE ANTENNAL SEGMENTS; 27, HIND TIBIA AND BASITARSUS (WINGS ABBREEVIATIONS ARE GIVEN IN FIGS. 1-9).

Materials examined: BANGLADESH: Faridpur, three +. Protomicroplitis sp., 18.VII.1999; 19.VII.1999. Collected by- M. Suza. Specimens deposited in ZMCU.

Microgastrines are found on all continents and from tropical to arctic climates. Many of the genera have more restricted distributions, or are more diverse in certain regions. In the New World, the dominant genera are Apanteles Foerster, Cotesia Cameron, Diolcogaster Ashmead, Dolichogenidea 
STUDY OF MICROGASTRINAE NEES 1814 (HYMENOPTERA: BRACONIDAE) IN BANGLADESH

Viereck, Glyptapanteles Ashmead and Microplitis Foerster. At least 50100 species and Apanteles represent each of these genera possibly by as many as 500 New World species (Wharton et al. 1997).

Twenty four species of Apanteles Foerster were reported by different authors (Alam 1962, 1967, Ali et al. 1995, Alam et al. 1964 and Gapud 1992) at different times from Bangladesh. Numerous species of Apanteles Foerster were described by different authors from India. Alam, (1967) and Ali et al., (1995) reported Microplitis similis Lyle from Bangladesh.

\section{ACKNOWLEDGEMENT}

Special thanks go to Dr. Donald Quicke, Imperial College of Science, Technology and Medicine, London for confirming the identifications. I would like to thank Professor Badrul Amin Bhuiya and Professor Dr. Ismail Miah, Department of Zoology, C.U. for their kind help in doing this work.

\section{REFERENCES}

ACHTERBERG, C.VAN. 1979. A revision of the subfamily Zelinae Auct. (Hymenoptera: Braconidae). Tijdsch. Ent. 122: 241-479.

ACHTERBERG, C.VAN. 1993. Illustrated key to the subfamilies of the Braconidae (Hymenoptera: Ichneumonoidea). Zool. Verh. Leiden. 283: 1-189.

ACHTERBERG, C.VAN. 1997. Revision of the subfamily Euphorinae (including the tribe Meteorini Cresson) (Hymenoptera: Braconidae) from China. Zool Verh. Leiden. 313: 1-217.

ALAM, M.Z. 1962. A List of Insects and Mites of East Pakistan. Department of Agriculture, East Pakistan (now Bangladesh). Government Press. Dhaka. pp. 82-90.

ALAM, M.Z. 1967. A Report on the Survey of Insect and Mite fauna of East Pakistan. East Pakistan Agricultural Research Institute, Ayubnagar, Dhaka. 147 pp.

ALAM, M.Z. AHMED, F., ALAM, S. AND ISLAM, M.A. 1964. A Review of Research. Division of Entomology (1946-1964). Agriculture Information Service. Dacca. $272 \mathrm{pp}$.

ALI, M.I., KARIM, M.A. AND CHOWDHURY, A.B.M.N.U. 1993. Natural enemies of cotton insect pests in Bangladesh. J. Asiat. Soc. Bangladesh (Sci.). 19(2):155-161. 
ALI, M.I., ISLAM, M.A. AND KABIR S.M.H. 1995. Biological control of insect and mite pests in important agricultural crops of Bangladesh. J. Asiat. Soc. Bangladesh (Sci.). 21 (2): 149-208.

GAPUD, V.P. 1992. Insect and Mite Pests of Plant Crops in Bangladesh and Their Natural Enemies. United State Agency for International Development/ Bangladesh Agricultural Research Council/ Checchi and Company Consulting Inc. 265 pp.

GOULET, H. AND HUBER, J.T. (EDS.). 1993. Hymenoptera of the World: An Identification Guide to Families. Research Branch, Agriculture Canada, Ottawa Publication 1894/E, 668 pp.

MASON, W.R.M. 1981. The polyphyletic nature of Apanteles Foerster (Hymenoptera: Braconidae): a phylogeny and reclassification of Microgastrinae. Mem. Ent. Soc. Can. 115: 1-147.

NIXON, G.E.J. 1965. A reclassification of the tribe Microgasterini (Hymenoptera: Braconidae). Bull. Brit. Mus. (Nat. Hist.) (Ent.) Suppl. 2: 1-284.

SHAW, M.R. AND HUDDLESTON, T. 1991. Classification and biology of braconid wasps (Hymenoptera: Braconidae). Handbooks for the Identification of British Insects. 7(11): 1-126.

SHENEFELT, R.D. 1972. Braconidae 4. Microgasterinae: Apanteles. Hymenopterorum Catalogus (nova editio). 7: 429-668.

SHENEFELT, R.D. 1973. Braconidae 5. Microgasterinae and Ichneutinae. Hymenopterorum Catalogus (nova editio). 9: 669-812.

WHARTON, R.A., MARSH, P.M. AND SHARKEY, M.J. 1997. Manual of the New World Genera of the Family Braconidae. Special Publication of The International Society of Hymenopterists, No. 1. 439 pp.

WHITFIELD, J.B. 1997. Microgastrinae. In: Manual of the New World Genera of the Family Braconidae (Hymenoptera). (R. Wharton, P. Marsh, and M. Sharkey, eds.). International Society of Hymenopterists (Special Publication 1), Washington. pp. 333-366.

YU D., ACHTERBERG, K.VAN AND HORSTMANN, K. 2005. World Ichneumonoidea 2004. Taxonomy, Biology, Morphology and Distribution. CD/DVD. Taxapad, Vancouver. 450 pp.

Manuscript received on 14.03.2012; Accepted on 07.07.2012

The Chittagong University Journal of Biological Sciences, Vol. $6(1$ \& 2). Page No. 